\title{
PELATIHAN PERMAINAN EDUKATIF UNTUK ANAK BERBASIS KOMPUTER PADA GURU DAN SISWA DI TK KATOLIK MALAEKAT PELINDUNG KOTA MANADO
}

\author{
Irene R. H. T. Tangkawarow \\ Fakultas Teknik, UNIMA \\ irene.tangkawarow@gmail.com
}

\begin{abstract}
Computer as a media learning is owned by TK Katolik Malaekat Pelindung in Manado city. However, limited knowledge of software application for early childhood makes computer studies at TK Malaekat Pelindung Kota Manado are often ineffective implemented. This situation causes stimulation for the child's intelligence are not fully achieved due to application of the games which used is unfit to the stage of early childhood development. The aims of this activity are: (1) To provide knowledge and understanding of the educational games application that correspond to the teachers and students at TK Katolik Malaekat Pelindung in Manado City. (2) To provide training for teachers and students on how to operate GCompris application.

GCompris application is qualified educational games application which consists of attractive interface, easy to use, and variety games inside. This training uses resident expert method. Resident expert method is a method of training with guidance from expert in information systems (in this case, the expert on the application GCompris).
\end{abstract}

Keywords: Computer, early childhood, GCompris, resident expert.

\section{PENDAHULUAN}

Pendidikan merupakan suatu kebutuhan setiap manusia dalam kehidupan, sebagai usaha dasar manusia untuk dapat mengembangkan potensi dirinya melalui proses pembelajaran dan atau cara lain yang dikenal dan diakui oleh masyarakat. Undang-UndangDasar Negara Republik Indonesia Tahun 1945 pasal 31 ayat (1) menyebutkan bahwa setiap warga negara berhak mendapatkan pendidikan. Oleh karena itu seluruh komponen bangsa wajib mencerdaskan kehidupan bangsa yang merupakan salah satu tujuan Negara Indonesia. Pendidikan merupakan aset penting bagi kemajuan sebuah bangsa. Oleh karena itu setiap warga Negara harus dan wajib mengikuti jenjang pendidikan, baik jenjang pendidikan anak usia dini, pendidikan dasar, pendidikan menengah maupun tinggi. Kebanyakan anak-anak Indonesia dalam memulai proses masuk ke lembaga pendidikan, mengabaikan pendidikan anak usia dini, padahal untuk membiasakan diri dan mengembangkan pola pikir anak pendidikan sejak usia dini mutlak diperlukan.

Dalam usia emas (golden age) tahapan perkembangan anak usia dini diperlukan banyak stimulasi untuk merangsang kecerdasan anak. Banyak lembaga-lembaga pendidikan anak usia dini yang sudah memanfaatkan komputer sebagai salah satu satu media untuk merangsang kemampuan otak anak. Melalui aplikasi-aplikasi komputer yang menarik berupa permainan-permainan edukatif yang menarik sesuai dengan tahap perkembangan anak usia. dini.

TK Katolik Malaekat Pelindung sudah menggunakan fasilitas komputer 
sebagai salah satu media pendukung pembelajaran. Namun sayangnya, keterbatasan pengetahuan akan aplikasi (software) pendukung pembelajaran yang mumpuni untuk anak usia dini membuat pelajaran komputer bagi siswa hanya menggunakan permaianan-permainan default dari sistem operasi Windows. Sehingga, stimulasi untuk kecerdasan dan kemampuan motorik anak tidak tercapai sepenuhnya karena aplikasi permainanpermainan tersebut bukanlah dikhususkan untuk tahap perkembangan anak usia dini.

GCompris adalah software edukasi/ pendidikan berkualitas yang berisi berbagai aktivitas untuk anak usia dini. Tentunya dengan tampilan yang menarik, cara pengoperasian yang mudah, dan konten permainan yang variatif dapat membuat anak-anak tidak cepat bosan.

Mitra dalam kegiatan ini ialah guru dan siswa TK Katolik Malaekat Pelindung Kota Manado yang berlokasi di Kelurahan Kleak Kecamatan Malalayang Kota Manado. Dari observasi awal dalam bentuk wawancara dengan Kepala Sekolah TK Katolik Malaekat Pelindung Kota Manado didapat-kan kesimpulan bahwa pengetahuan guru tentang aplikasi komputer yang cocok untuk menstimulasi kecerdasan anak usia dini masih kurang.

Berdasarkan analisis situasi dan identifikasi permasalahan mitra maka diperoleh beberapa fakta pokok yang menjadi prioritas permasalahan, yaitu:
1. Kurangnya pengetahuan guru tentang aplikasi komputer permainan edukatif yang cocok bagi anak usia dini.

2. Kurangnya pengetahuan guru tentang cara pengoperasian salah satu aplikasi komputer edukatif bagi anak usia dini.

\section{KAJIAN LITERATUR}

\section{Permainan Edukatif}

Permainan edukatif adalah semua bentuk permainan yang dirancang untuk memberikan pengalaman pendidikan atau pengalaman belajar kepada para pemainnya, termasuk Permainan tradisional dan "modern" yang diberi muatan pendidikan dan pengajaran (A.Prianto, 2010). Atas dasar pengertian itu, permainan yang dirancang untuk memberi informasi atau menanamkan sikap tertentu, misalnya untuk memupuk semangat kebersamaan dan kegotongroyongan, termasuk dalam kategori permainan edukatif karena permainan itu memberikan pengalaman belajar kognitif dan afektif. Dengan demikian, tidak menjadi soal apakah permainan itu merupakan permainan "asli" yang khusus dirancang (by design) untuk pendidikan ataukah permainan "lama" yang diberi nuansa atau dimanfaatkan (by utilization) untuk pendidikan.

Permainan edukatif merupakan suatu kegiatan yang sangat menyenangkan dan dapat merupakan cara atau alat pendidikan yang bersifat mendidik dan bermanfaat untuk meningkatkan 
kemampuan berbahasa, berpikir serta bergaul dengan lingkungan atau untuk menguatkan dan menterampilkan anggota badan si anak, mengembangkan kepribadian, mendekatkan hubungan antara pendidik dengan peserta didik, kemudian menyalurkan kegiatan anak didik dan sebagainya.

Permainan edukatif juga dapat berarti sebuah bentuk kegiatan yang dilakukan untuk memperoleh kesenangan dari cara atau media pendidikan yang digunakan dalam kegiatan bermain, yang disadari atau tidak, memiliki muatan pendidikan yang dapat bermanfaat dalam mengembangkan diri peserta didik.Artinya, permainan edukatif merupakan sebuah bentuk kegiatan mendidik yang dilakukan dengan menggunakan cara atau media permainan yang bersifat mendidik. Ringkasnya, permainan edukatif adalah permainan yang bersifat mendidik.

Dunia anak adalah dunia bermain, melalui bermain anak memperoleh pelajaran yang mengandung aspek perkembangan kognitif, sosial, emosi dan perkembangan fisik. Melalui kegiatan bermain dengan berbagai permainan anak dirangsang untuk berkembang secara umum baik perkembangan berpiikir, emosi maupun sosial.

Anak-anak usia 2-8 tahun merupakan anak pada tahap praoperasional. Menurut Piaget ciri pokok perkembangan pada tahap ini adalah pada penggunaan simbol atau bahasa tanda, dan mulai berkembangnya konsep-konsep intuitif. Praoperasional (2-4tahun )pada usia ini anak telah mampu menggunakkan bahasa dalam mengembangkan konsepnya, walaupun masih sangat sederhana. Karakteristik pada tahap ini adalah: (1) Self counter sangat menonjol; (2) Dapat mengklasifikasikan objek pada tingkat dasar secara tunggal dan mencolok; (3) Tidak mampu memusatkan perhatian pada objek-objek yang berbeda; (4) Mampu mengumpulkan barang-barang menurut kriteria termasuk kriteria yang benar; dan (5) Dapat menyusun benda-benda secara berderet, tetapi tidak dapat menjelaskan perbedaan antara deretan.

Tahap Intuitif (4-8 tahun) memiliki karakteristik: (1) anak mampu membentuk kelas-kelas, tapi kurang menyadari maksudnya; (2) anak mulai mengerti hubungan logis pada hal-hal yang kompleks; (3) anak dapat melakukan sesuatu terhadap sejumlah ide; (4) anak mampu memperoleh prinsip secara benar.

Pendidikan anak usia dini $(0-8$ tahun) merupakan tempat belajar sekaligus bermain bagi anak-anak. Anak-anak diajarkan mengenal aturan, disiplin, tanggung jawab dan kemandirian dengan cara bermain. Anak juga diajarkan bagaimana mereka harus menyesuaikan diri dengan lingkungannya, berempati dengan temannya, tentunya juga berlatih bekerja sama dengan anak yang lain.

Melalui kegiatan bermain yang mengandung edukasi, daya pikir anak 
terangsang untuk merangsang perkembangan emosi, perkembangan sosial dan perkembangan fisik. Setiap anak memiliki kemampuan dan ketertarikan bermain yang berbeda tergantung dari perkembangan anak. Dari permainan juga biasanya akan menimbulkan fantasi-fantasi besar oleh anak, dan tentu akan semakin menambah rasa ketertarikan anak pada mainan tersebut. Menurut Sudono (Sudono, 2006), permainan edukatif penting bagi anak-anak, disebabkan karena:

1. Permainan edukatif dapat membantu anak dalam mengembangkan dirinya.

2. Permainan edukatif mampu meningkatkan kemampuan berkomunikasi bagi anak.

3. Permainan edukatif mampu membantu anak dalam menciptakan hal baru atau memberi inovasi pada suatu permainan.

4. Permainan edukatif mampu meningkatkan cara berpikir pada anak.

5. Permainan edukatif mampu meningkatkan perasaan anak.

6. Permainan edukatif mampu meningkatkan rasa percaya diri pada anak.

7. Permainan edukatif mampu merangsang imajinasi pada anak.

8. Permainan edukatif dapat melatih kemampuan bahasa pada anak

9. Permainan edukatif dapat membentk moralitas anak.

10. Permainan edukatif dapat mengembangkan sosialisasi pada anak.

Dalam menentukan permainan edukatif, orang tua atau pendidik harus 16 pintar pintar dalam memilih, karena tidak semua yang harganya mahal dan modern itu bersifat mendidik, bisa jadi itu hanya menanamkan sifat konsumtif pada anak. Untuk digunakan di sekolah, selayaknya pendidik dapat memilih dan menyediakan media-media yang dapat mendukung perkembangan kepribadian anak, yang menyangkut fisik, intelektual, sosial, moral dan emosional anak.

\section{Aplikasi GCompris}

GCompris adalah software edukasi/ pendidikan berkualitas yang berisi berbagai aktivitas untuk anak usia dini (Coudoin, 2014). Beberapa aktivitas berorientasi permainan tapi tetap mendidik. Di bawah ini daftar kategori dengan beberapa aktivitas yang tersedia dalam kategori tersebut:

- Pengenalan Komputer: keyboard, mouse, gerakan mouse yang berbeda;

- Aljabar: tabel memori, urutan, tabel pemasukan ganda, mencerminkan gambar;

- Ilmu pengetahuan alam: pintu kanal, siklus air, kapal selam, simulasi listrik;

- Geografi: menempatkan negara di peta;

- Permainan: catur, memori, sambung 4, oware, sudoku;

- Membaca: praktek membaca; dan

- Lain-lain: belajar membaca jam, tekateki lukisan terkenal, gambar vektor, pembuatan kartun.

Saat ini GCompris berisi lebih dari 100 aktivitas dan masih sedang 
dikembangkan. GCompris adalah perangkat lunak bebas, yang berarti kita dapat menggunakannya sesuai dengan kebutuhan, memperbaikinya, dan yang paling penting, berbagi dengan anak-anak di mana-mana.

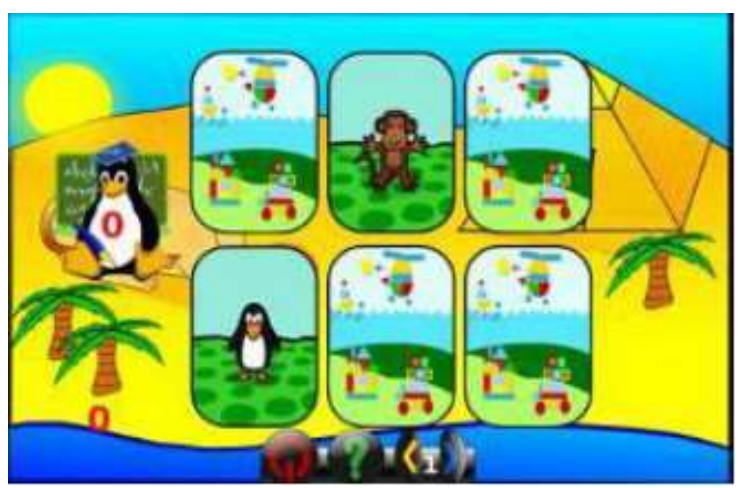

Gambar 1. Tampilan aplikasi GCompris

\section{METODOLOGI KEGIATAN}

Pendekatan kegiatan ini dilakukan dengan menggunakan metode pelatihan bentuk resident expert. Metode ini adalah metode pelatihan yang menggunakan bantuan atau tenaga dari para ahli dibidang sistem. Dengan menggunakan metode ini diharapkan guru dan siswa akan lebih mudah dalam menggunakan aplikasi komputer permainan edukatif GCompris.

Kegiatan pelatihan aplikasi GCompris kepada Guru dan siswa-siwsa TK Katolik Malaekat Pelindung Kota Manado dilaksanakan di Laboratorium TK. Waktu kegiatan ialah dua hari yakni pada Senin, 16 Mei 2016 dan Selasa, 17 Mei 2016.

\section{HASIL DAN PEMBAHASAN}

Bentuk kongkret langkah-langkah pelaksanaan kegiatan Pelatihan aplikasi edukatif ini dimulai dari tahap awal sampai dengan tahap akhir yakni terlaksananya kegiatan ialah sebagai berikut:

1. Mengidentifikasi masalah-masalah penyerapan materi pengenalan huruf, angka, warna, bentuk, dll dengan menggunakan aplikasi komputer melalui permaianan edukatif pada TK/ PAUD

2. Teridentifikasi bahwa masalah yang sangat urgen untuk dipecahkan ialah masalah penggunaan aplikasi komputer yang sangat kurang pemanfaatannya.

3. Menentukan bentuk pemecahan masalah yang dapat ditawarkan bagi TK Katolik Malaekat Pelindung Kota Manado adalah dengan pelatihan aplikasi komputer yang edukatif.

4. Pelaksanaan kegiatan dilangsungkan selama dua hari dengan berhasil diikuti semua siswa yang hadir dan guru-guru.

5. Jumlah peserta penyuluhan yang mencapai kurang lebih 65.

6. Tercapainya tujuan kegiatan ialah terukur maksimalnya pemberian materi pelatihan dan kemampuan siswa dan guru dalam mengoperasikan/ menggunakan aplikasi GCompris.

Berdasarkan pengamatan dan evaluasi yang dilakukan selama kegiatan pelatihan ini ini maka dapat dilaporkan bahwa kegiatan pelatihan dimaksud telah berhasil dilaksanakan dengan waktu pelaksanaan selama dua hari dengan perincian 3 jam perhari dengan total 6 jam. Indikator keberhasilan pemberian materin penyuluhan dapat diukur dari: 
1. Peserta (guru dan siswa-siswa) dapat membuka aplikasi GCompris sendiri tanpa bantuan pemateri.

2. Peserta (guru dan siswa-siswa) dapat menggunakan serta mengoperasikan aplikasi GCompris sendiri tanpa bantuan pemateri.

Faktor pendukung dari kegiatan ini ialah adanya komitmen Kepala Sekolah serta guru-guru untuk menggunakan aplikasi komputer sebagai salah satu media pembelajaran pendukung, yang dibuktikan memfasilitasi waktu dan lokasi pelaksanaan kegiatan pelatihan aplikasi komputer.

Faktor penghambat kegiatan pelatihan ini ialah adanya kesulitan penentuan waktu kegiatan pelatihan yang harus disesuaikan dengan jam belajar siswa TK.

\section{KESIMPULAN}

Kesimpulan dalam pelaksanaan kegiatan pengabdian kepada masyarakat ini adalah:
1. Penggunaan aplikasi komputer sebagai salah satu media pembelajaran dapat merangsang minat dan keaktifan belajar siswa.

2. Pelatihan aplikasi komputer edukatif untuk PAUD berhasil dilaksanakan dengan indikator inti adanya antusiasme guru dan siswa untuk mengikuti kegiatan pelatihan ini.

3. Terjalinnya hubungan kemitraan antara akademisi bahkan lembaga Universitas Negeri Manado dengan TK Katolik Malaekat Pelindung Kota Manado.

\section{KEPUSTAKAAN}

A.Prianto, R. M. (2010). Perilaku Anak Usia Dini Perilaku dan Pemecahannya. Jakarta: Familia.

Coudoin, B. (2014, Februari 9). GCompris. (GNU General Public License) Retrieved March 25, 2014, from http://gcompris.net/index-en.html

Sudono, A. (2006). Belajar dan Alat Permainan (untuk Pendidikan Anak Usia Dini). Jakarta: Grasindo. 